\title{
CALCULATION CLEARANCE BETWEEN AIRCRAFT
}

\author{
Hartono \\ LAPAN - Pusat Teknologi Penerbangan \\ J1. Raya Lapan Rumpin, Sukamulya, Bogor - Jawa Barat \\ hartono.danki@gmail.com
}

\begin{abstract}
Airport aprons, aprons, ramps, or asphalt, are areas of an airport where aircraft are parked, unloaded or loaded, refueled, or ridden. Although the use of an apron is covered by regulations, such as lighting on a vehicle, it is usually more accessible to users than a runway or taxiway. The method used is to look at the rules or regulations in force in Indonesia, namely on Peraturan Direktur Jenderal Perhubungan Udara, No : SKEP/77/VI/2005 about Persyaratan Teknis Pengoperasian Fasilitas Teknik Bandar Udara. In this study, the extent of apron needs with the ability to accommodate 2 to 3 aircraft will be calculated. If the calculation results use aircraft specifications N219 (Nurtanio) and Stemme $S-15$, the Clearance between aircraft ready to takeoff is $556.5 \mathrm{~m} 2$.
\end{abstract}

Keyword : Apron, Runway, Taxiway, Airport, Aircraft

\section{Introduction}

Facilities Airplane parking (Apron) is an air-side facility provided as a place for aircraft when carrying out activities to raise and lower passengers, post and cargo loads from aircraft, refueling, parking and aircraft maintenance. Components of the apron include the aircraft stands (gates), the taxiways, the service roads, and the aircraft stand taxi lanes [1]. Apron is a part of the airport that serves the terminal so that it must be design according to the needs and characteristics of the terminal. Some of the considerations include:

a. Provides the shortest distance between the runway and where the plane stops.

b. Providing flexibility in aircraft movements to maneuver so as to reduce delays.

c. Provide sufficient area development reserves needed if there will be an increase in flight demand or the development of aircraft technology.

d. To provide maximum user efficiency, safety and comfort.

e. Minimizing environmental impacts

The area is influenced by the type of aircraft served and the number and types of landing and flight equipment required to support the airport's operational performance. Aspects that are considered in the assessment of operational feasibility include dimensions (length and width), longitudinal slope, transverse slope, type of pavement (Surface Type), and strength.

Apron is a parking lot that has the same construction as Runway and Taxiway. Apron serves as a place for loading of passengers or goods from or to the aircraft. The location of the aircraft parking lot must not violate the barrier of obstacles that are on the surface and especially inside. The size of the plane parking lot must be sufficient to be able to serve the maximum traffic flow needed.

\section{Refference and Methods}

\subsection{Dimension (Length, width)}

The three main components of an airport are the building terminal(s), the apron, and the runways [2]. The layout design of the apron is the main focus of this study. The terminals at 
an airport are used to process passengers, crew, and cargo, and to facilitate their movement on and off the aircraft. They serve as transfer areas, and are therefore not starting and end points for passengers and cargo [3].

In figure 1 it can be seen that the terminal building is parallel to the apron facing the taxiway and runway area. The aircraft parking lot must not violate barriers on the surface and especially inside [4].

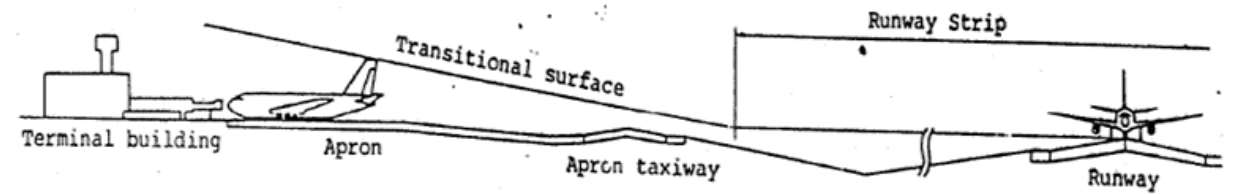

Figure 1. Side Section of Apron [4]

The total apron area should be adequate to permit expeditious handling of the aerodrome traffic at its maximum anticipated density [5].

Table 1. Apron Dimension [4]

\begin{tabular}{|l|c|c|c|c|c|c|}
\hline \multirow{2}{*}{ Description } & \multicolumn{7}{c|}{ Aircraft Classification } \\
\cline { 2 - 7 } & I & II & III & IV & V & VI \\
\hline 1. Dimensions For One Plane & & & & & & \\
\hline Slef Taxing (45o taxiling) & & & & & & \\
\hline Length (m) & 40 & 40 & 70 & $70-85$ & $70-85$ & $70-85$ \\
\hline Witdh (m) & 25 & 25 & 55 & $55-80$ & $55-80$ & $55-80$ \\
\hline Nose In & & & & & & \\
\hline Length (m) & - & & 95 & 190 & 190 & 190 \\
\hline Witdh (m) & - & & 45 & 70 & 70 & 70 \\
\hline $\begin{array}{l}\text { Clearence Between Aircraft On The } \\
\text { Apron }\end{array}$ & 3 & 3 & 4,5 & 4,5 & 4,5 & 4,5 \\
\hline 2. Slope & & & & & & \\
\hline Parking Area, Maximum & $1 \leq$ & $1 \leq$ & $1 \leq$ & $1 \leq$ & $1 \leq$ & $1 \leq$ \\
\hline Fuel Loading Area & $+1 / 2$ & $+1 / 2$ & $+1 / 2$ & $+1 / 2$ & $+1 / 2$ & $+1 / 2$ \\
\hline
\end{tabular}

The table showing description about dimensions for one plane, slope for classification aircraft will chose. In figure 2 will explain the rules of each position in the aircraft parking lot from the runway center line.

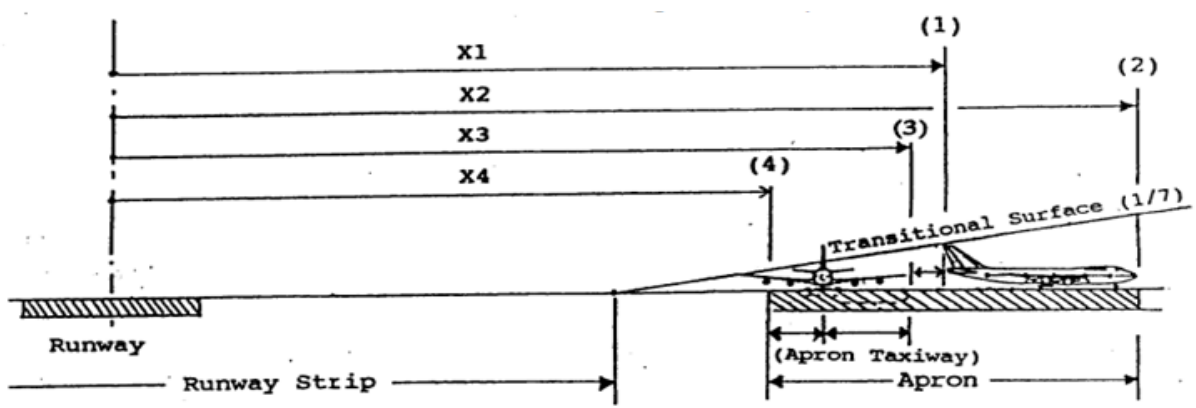

Figure 2: Apron dan Taxiway Position (X1) Maximum position from the plane's tail to the runway centerline. (X2) Position from runway center line to terminal building. (X3) Position of the wing of the aircraft that is next to the terminal building. (X4) Position of the end of the plane's parking [4] 

follows:

The position of each in the airplane parking from the runway centers line is set as

$\mathrm{X} 1=$ The maximum position from the plane's tail to the runway centerline

$\mathrm{X} 2=$ Position from runway center line to terminal building

$(\mathrm{X} 2=\mathrm{X} 1+$ maximum plane length)

$\mathrm{X} 3=$ The position of the wing of the aircraft that is next to the terminal building to the runway centerline

$(\mathrm{X} 3=\mathrm{X} 1$ - distance between two planes $)$

$\mathrm{X} 4=$ The position of the end of the plane's parking lot up to the runway centerline

$(\mathrm{X} 4=\mathrm{X} 3$ - Maximum width of the plane / 2)

Table 2: Inter-plane Free Distance at Apron [4]

\begin{tabular}{|l|c|c|c|c|c|c|}
\hline \multirow{2}{*}{ Description } & \multicolumn{7}{c|}{ Aircraft Classification } \\
\cline { 2 - 7 } & A/I & B/II & C/III & D/IV & E/V & F/VI \\
\hline $\begin{array}{l}\text { Clearance between aircraft ready to } \\
\text { takeoff (A) (m) }\end{array}$ & 10 & 10 & 10 & 15 & 15 & 15 \\
\hline $\begin{array}{l}\text { Clearance between aircraft on } \\
\text { taxiline (B) (m) }\end{array}$ & 4,5 & 4,5 & 7,5 & 7,5 & 10 & 10 \\
\hline $\begin{array}{l}\text { Clearance between aircraft on lead- } \\
\text { in (C) (m) }\end{array}$ & 4,5 & 4,5 & 7,5 & 7,5 & 10 & 10 \\
\hline $\begin{array}{l}\text { Clearance between aircraft on other } \\
\text { building apron (D) (m) }\end{array}$ & 4,5 & 4,5 & 7,5 & 7,5 & 10 & 10 \\
\hline $\begin{array}{l}\text { Clearance between aircraft with } \\
\text { fuel tank (E) (m) }\end{array}$ & 15 & 15 & 15 & 15 & 15 & 15 \\
\hline
\end{tabular}

In order to better understand the apron operating environment, site visits were conducted to airports that provided the types of apron facilities of interest in this research project (terminal apron, deicing aprons, general aviation aprons, etc.). These site visits provided a greater understanding of the operational and physical influences on apron configurations [6].

In accordance with applicable regulations, then in figure 3 , the clearance of the aircraft with its surroundings is explained based on the classification of the aircraft. 


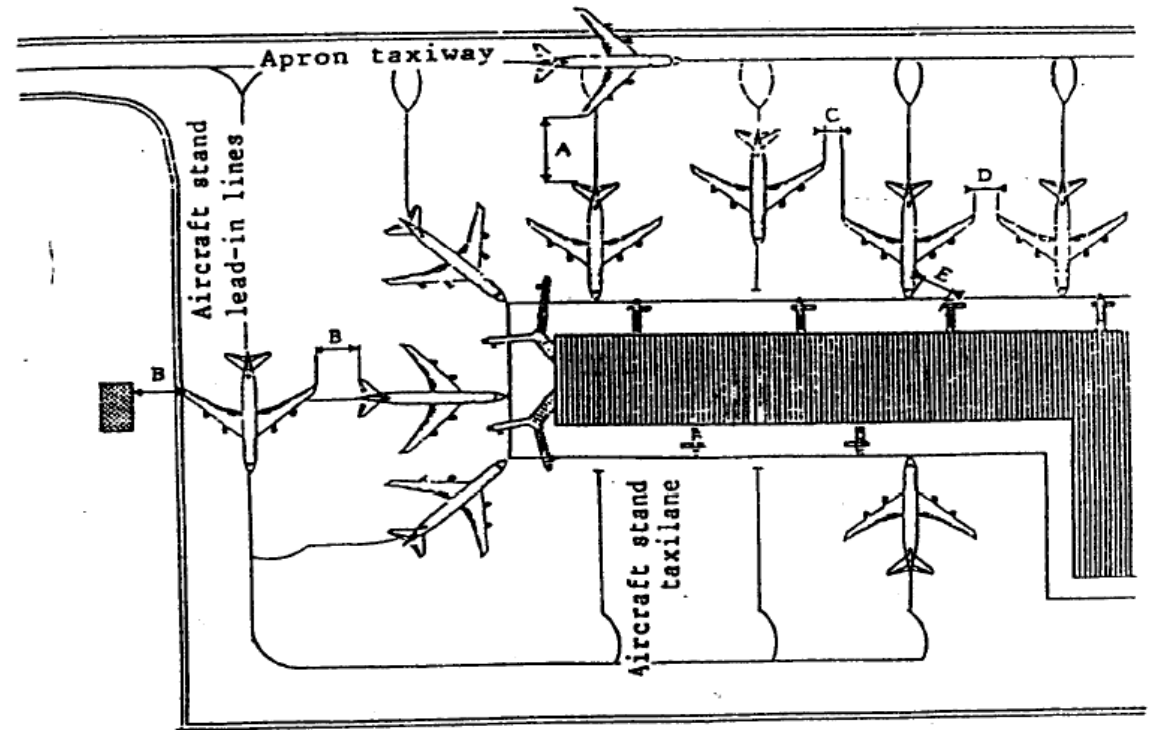

Figure 3. Apron Configuration (A) Clearance between aircraft ready to takeoff . (B) Clearance between aircraft on taxiline. (C) Clearance between aircraft on lead-in. (D) Clearance between aircraft on other building apron. (E) Clearance between aircraft with fuel tank [4]

\subsection{Flow Diagram}

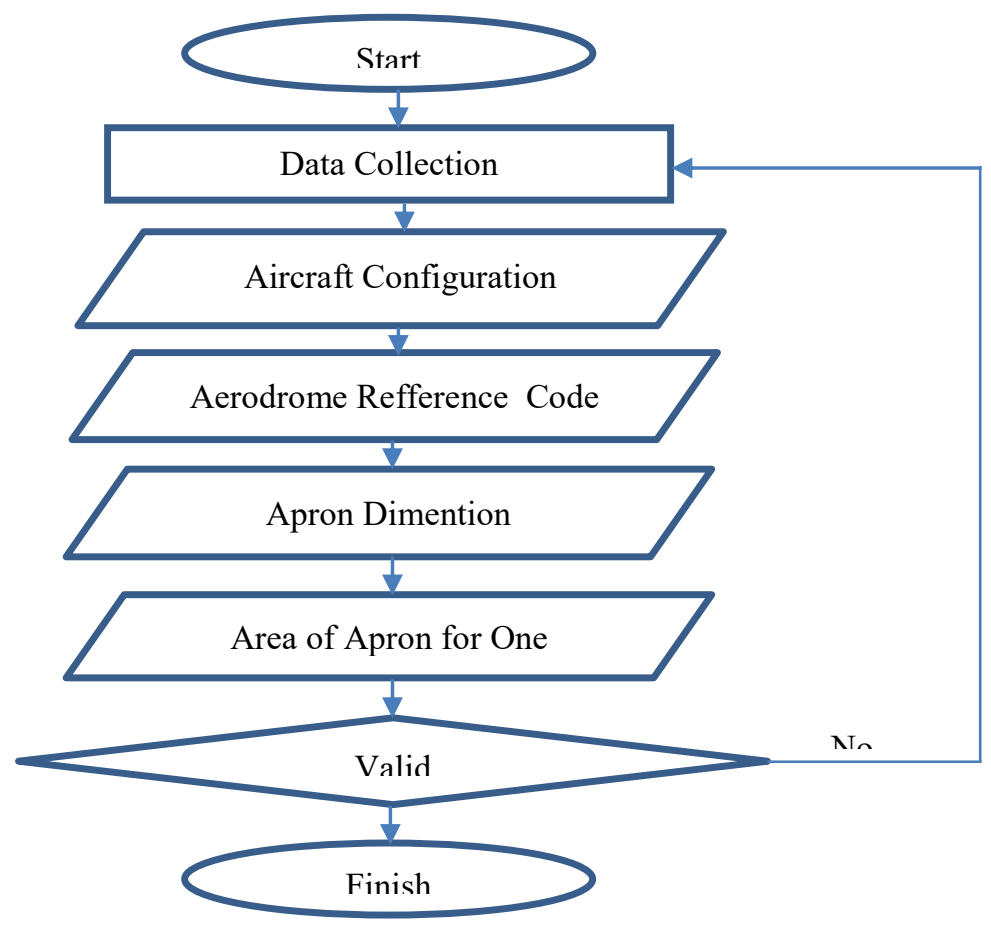

Figure 4.Flow diagram of research

\section{Results and Discussion}

\subsection{Aircraft Configuration}

For planning the apron, the value based on the widest wingspan of the STEMME S-15 aircraft type (PK-LSA) and the longest length of aircraft type N219. 
- Wing span $\quad=18 \mathrm{~m}($ STEMME S-15)

- Length $=16,5 \mathrm{~m}(\mathrm{~N} 219)$

- Aerodrome ref. code $=2 \mathrm{~B}$

\subsection{Apron Dimension}

Refference in table 1 shows the classification of aircraft based on dimensions for one plane (Slef Taxing, Nose in and clearance between planes at Apron) and Slope (in place of parking aircraft and fuel loading area).

a. Dimensions For One Plane

1) Slef Taxing (45o taxiling)

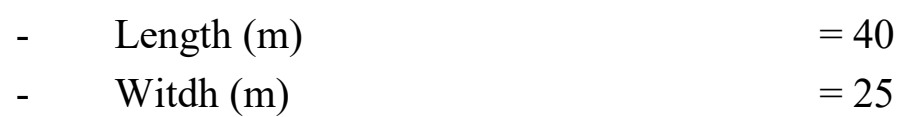

2) Nose In

- Length $(\mathrm{m}) \quad=$ -

- Witdh (m) =

3) Clearence Between Aircraft On The Apron = 3

b. Slope

1) Parking Area, Maximum =1 $\leq$

2) Fuel Loading Area $=+1 / 2$

Note : In this design use slope at the apron of $0.8 \%$

\subsection{Clearance between aircraft}

The apron area is defined by the total number of stands, number of stands per aircraft type, gate usage policy, its position with respect to the runway system, and their mutual functional relations through the taxiway system, as well as by the apron taxiway system, ground handling characteristics, and other relevant factors [7].

According to ICAO Annex 14, Aircraft parking position taxiline must be separated from opposite objects with distances not less than specified using the following table:

Table 3: Distance of aircraft edge parking.

\begin{tabular}{|c|c|}
\hline Code Letter & Clearance \\
\hline A & $3 \mathrm{~m}$ \\
B & $3 \mathrm{~m}$ \\
C & $4.5 \mathrm{~m}$ \\
D & $7.5 \mathrm{~m}$ \\
E & $7.5 \mathrm{~m}$ \\
F & $7.5 \mathrm{~m}$ \\
\hline
\end{tabular}

In this design, the free distance between parking lots is $3 \mathrm{~m}$.

Apron area is used for pre-flight activities including parking, waiting, and maintenance. As there is an association relationship between apron area and gate, hence, apron is needed to be defined as a separate entity which consists of apron identifier and its state [8]. 
The regulations for the director general of air transportation SKEP / 77 / VI / 2005 [4], which regulates the free distance between aircraft at the apron, and reffer to table 2:
Clearance between aircraft ready to takeoff $(\mathrm{A})(\mathrm{m})$
$=10$
Clearance between aircraft on taxiline
(B) $(\mathrm{m})$
$=4,5$
Clearance between aircraft on lead-in (C) (m)
$=4,5$
Clearance between aircraft on other buil
uilding apron $(\mathrm{D})$
$(\mathrm{D})(\mathrm{m})=4,5$
Clearance between aircraft with fuel tank (E) (m)
$=15$

Whereas based on Federal Aviation Administration (FAA) regulations on Airport Design 150-5300-13 [9], for configuration of push-out / power out the distance between the nose of the aircraft and terminal buildings varies greatly from 4.5 to $9 \mathrm{~m}$ or more. So that in this design a $4.5 \mathrm{~m}$ free distance is used.

Then the apron area needed for one aircraft with the largest wingspan is:

A $=($ wing span + clearance $) \times($ length + clearance $)$

$=(18+3) \times(16,5+10)$

$=556,5 \mathrm{~m}^{2}$

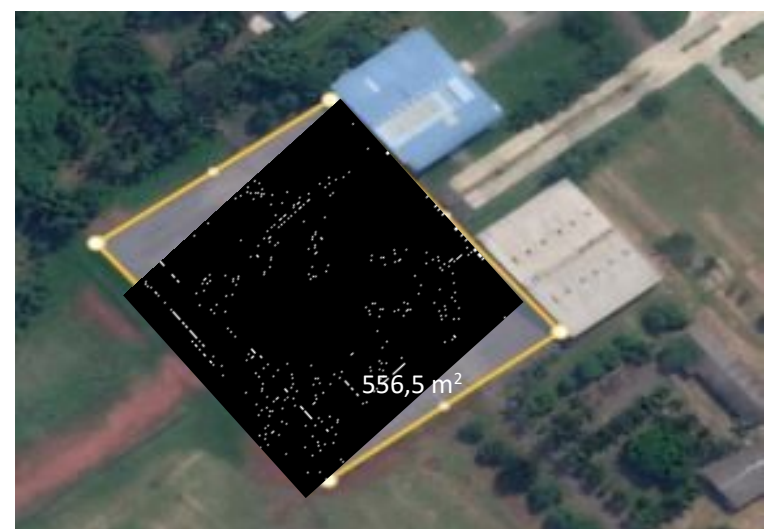

Figure 4: Clearance between aircraft ready to takeoff

$\mathrm{B}=($ wing span + clearance $) \times($ length + clearance $)$

$$
=(18+3) \times(16,5+4,5)
$$

$=441 \mathrm{~m}^{2}$

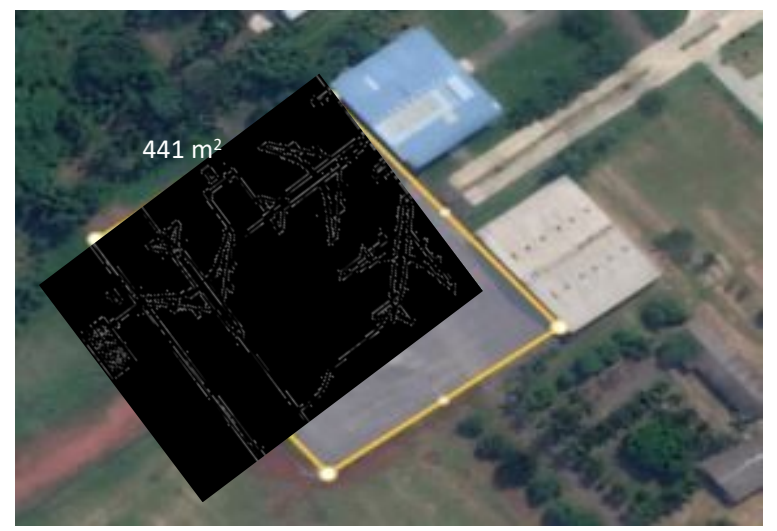

Figure 5: Clearance between aircraft on taxiline 
$\mathrm{C}=($ wing span + clearance $) \times($ length + clearance $)$

$=(18+3) \times(16,5+4,5)$

$=441 \mathrm{~m}^{2}$

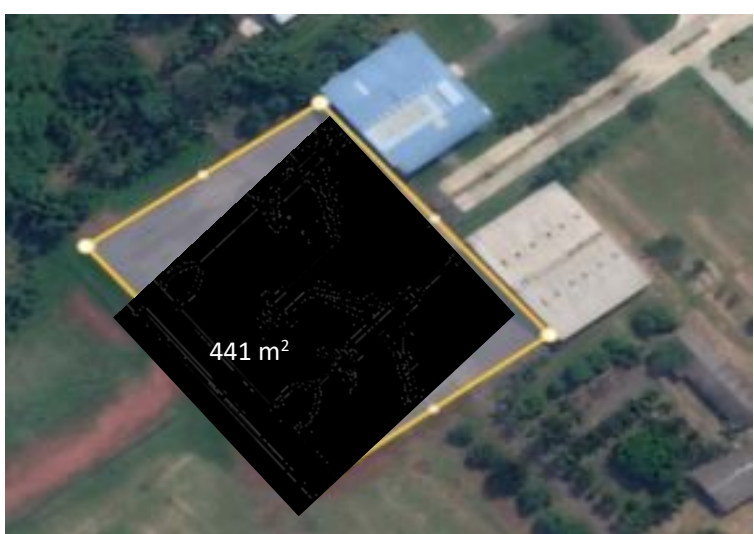

Figure 6: Clearance between aircraft on lead-in

$\mathrm{D}=($ wing span + clearance $) \times($ length + clearance $)$

$=(18+3) \times(16,5+4,5)$

$=441 \mathrm{~m}^{2}$

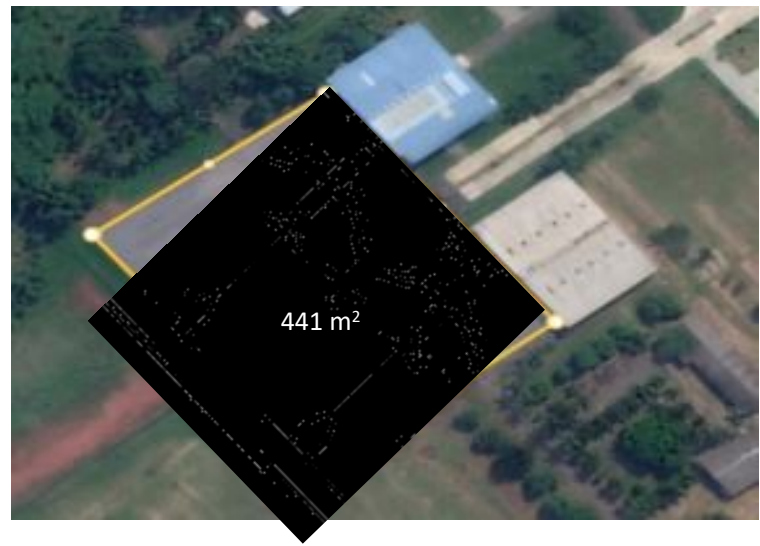

Figure 7: Clearance between aircraft on other building apron

$\mathrm{E}=($ wing span + clearance $) \times($ length + clearance $)$

$=(18+3) \times(16,5+15)$

$=661,5 \mathrm{~m}^{2}$

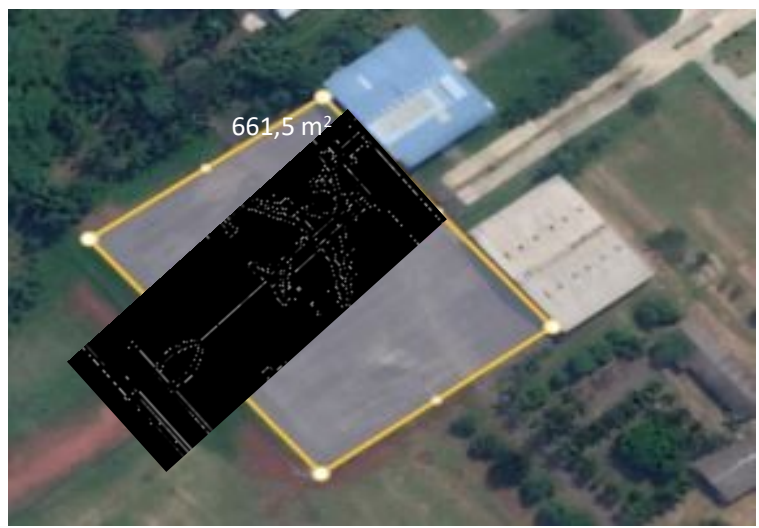

Figure 8: Clearance between aircraft with fuel tank 


\section{Conclusions}

This paper presented a calculation clearance between for apron aircraft on Aeronautic Technology Center. Where calculation clearance between aircraft ready to takeoff (A) is $556,5 \mathrm{~m}^{2}$. Clearance between aircraft on taxi line (B), clearance between aircraft on lead-in (C), clearance between aircraft on other building aprons (D) is $441 \mathrm{~m}^{2}$ and clearance between aircraft with fuel tank (E) is $661,5 \mathrm{~m}^{2}$.

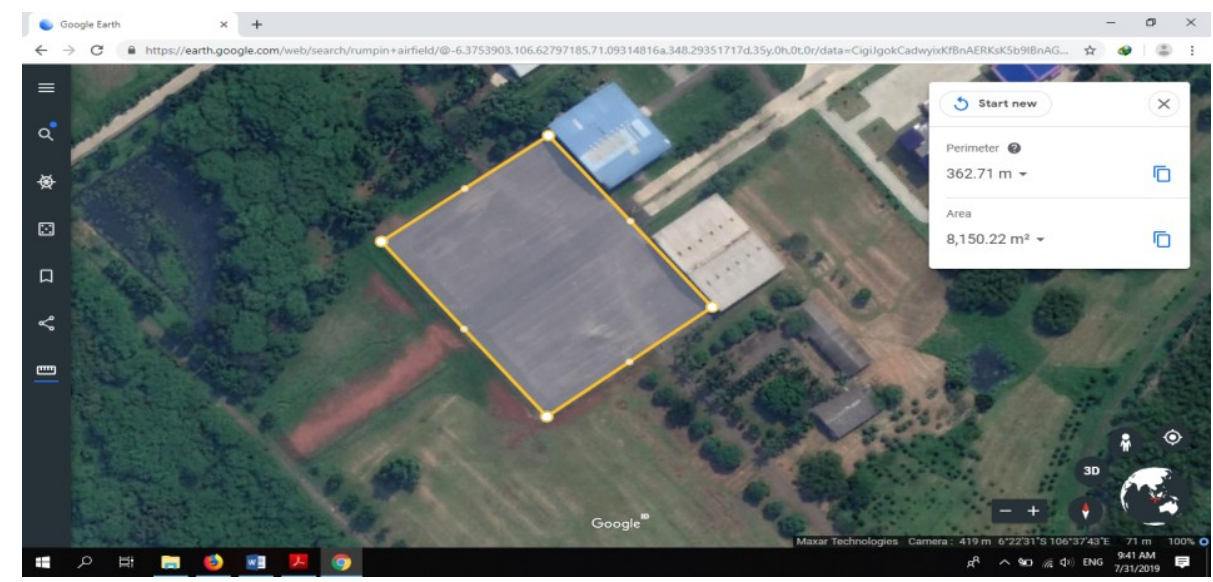

Figure 9: The area of the apron currently at Aeronautic Technology Center

(Source : https://earth.google.com/web/search/rumpin+airfield/@,$\underline{6.3753903,106.62797185,71.09314816 \mathrm{a}, 348.29351717 \mathrm{~d}, 35 \mathrm{y}, 0 \mathrm{~h}, 0 \mathrm{t}, 0 \mathrm{r} / \mathrm{data}=\text { CigiJgokCadwyix }}$ KfBnAERKsK5b91BnAGYqjM5DzqVpAIUXj-bW4plpA)

With the current conditions (see figure 9), the apron from the Aeronautic Technology Center is expected to be adjusted to the existing calculations. So that it can meet standards in accordance with applicable regulations.

Decision makers therefore need to find a way of evaluating all the indicators of the airport's effectiveness while considering their tradeoffs. Computer simulation is a useful technique to use to consider the needs of all stakeholders and address their conflicting objectives, because future concepts can be tested, timetable feasibility evaluated, different runway configurations compared, and bottlenecks identified at a fraction of the cost of realworld testing [10].

This implies that apron capacity problems are specific to each airport and usually observed, modeled, and resolved at the local level. It is very difficult to isolate these relations fromthe entire airfield system, which is why apron models usually exist as one of the modules of integrated simulation models [7].

One of the issues related to airport airside capacity planning and management that is usually pushed aside, giving priority to huge infrastructural changes (building of a new runway or new terminal complex). It deals with apron development that, together with the development of other elements (taxiways, curbside, etc.), should follow expected changes in demand, in order to maintain efficient functioning of the entire system [2].

\section{Acknowledgments}

The author is grateful for all the comments and suggestions provided by reviewers and editors. They certainly contributed in making the revised version of the paper more focused and closer related to the problem addressed. This research work is supported by the Aeronautic Technology Center, Indonesia. 


\section{Referece}

[1] A.T. Wells \& Young, S.B. (2004). "Airport planning and management," McGraw-Hill, New York.

[2] T. Leonard \& J. Bekker. (2013) "Apron layout design and flight-to-gate assignment at lanseria international airport," South African Journal of Industrial Engineering Vol 24(1): pp 192-206. South Africa.

[3] N. Ashford, Stanton, H.P.M. \& Moore, C.A. (1997) “Airport operations,” McGrawHill, New York.

[4] Peraturan Direktur Jenderal Perhubungan Udara. (2005) "Nomor. : SKEP / 77 / VI / 2005," pp. 40-43. Jakarta.

[5] International Civil Aviation Organization (ICAO). (2009) "Aerodrome Design and Operations," Annex 14, Volume I, New York.

[6] Ricondo \& Associates, Inc. (2013) “Apron planning and design guidebook," Chicago.

[7] M. Bojana \& T. Vojin. (2013) "Airport apron capacity: estimation, representation, and flexibility," Journal Of Advanced Transportation J. Adv. Transp. 2014; 48:97-118, DOI: $10.1002 /$ atr.1250

[8] Nazir Ahmad Zafar, Fahad Alhumaidan, and Sher Afzal Khan. (2014). "Z Specification of Gate and Apron Control Management at Airport". Hindawi.Volume 2014, Article ID 530619, 9 pages. http://dx.doi.org/10.1155/2014/530619

[9] Federal Aviation. Administration's (FAA). (2008) “Advisory Circular 150/5300-13, Airport Design," New York.

[10] H. Offerman. (2001) "Simulation to support the airport stakeholder decision-making process,” Air \& Space Europe 3(1-2), pp. 60-67. doi:DOI:10.1016/S1290-0958(01) 90017-6. 